\title{
The effects of firm's innovation on customer's loyalty: A case study of Saigon COOP
}

\author{
Bui Quang Hung ${ }^{1}$, Trinh Thuy $\mathrm{Anh}^{2 *}$, Nguyen Thi Thu Thao ${ }^{2}$, Nguyen Pham Kien Minh ${ }^{2}$ \\ ${ }^{1}$ University of Economics Ho Chi Minh City, Vietnam \\ ${ }^{2}$ Ho Chi Minh City Open University, Vietnam \\ ${ }^{*}$ Corresponding author: thuyanh@ou.edu.vn
}

\begin{tabular}{|c|c|}
\hline ARTICLE INFO & ABSTRACT \\
\hline $\begin{array}{l}\text { Keywords: } \\
\text { marketing innovation, } \\
\text { products/service innovation, } \\
\text { social media innovation, } \\
\text { customer's loyalty, customer } \\
\text { satisfactions, consumer } \\
\text { perceived value }\end{array}$ & $\begin{array}{l}\text { Identifying how the innovation affects the customer's loyalty } \\
\text { via the consumer perceived value and customer satisfactions from } \\
\text { products or services provided by the Coopmart Retailers System } \\
\text { in Ho Chi Minh City, Vietnam is the purpose of this search. This } \\
\text { research also draws some suggestions for the firm's future } \\
\text { development. The research was conducted through } 2 \text { phases: a } \\
\text { qualitative pilot study and quantitative analysis. The pilot study } \\
\text { was conducted with } 5 \text { people who are working in Coopmart as } \\
\text { department heads, deputy heads, and managers with at least } 10 \\
\text { years' experience. The qualitative survey will be distributed in the } \\
\text { Ho Chi Minh City Coopmart system's customers with member } \\
\text { cards where } 291 \text { valid surveys were qualified for further analysis. } \\
\text { This research's insight is the impacts of innovation on the } \\
\text { consumer perceived value, which has few focuses from previous } \\
\text { studies. The outcome of the research has shown different aspects } \\
\text { of the innovation to the consumer perceived value and customer } \\
\text { satisfactions. }\end{array}$ \\
\hline
\end{tabular}

\section{Introduction}

Reported by the General Statistics Office of Vietnam, the retail sector contributes over 14\% total GDP of Vietnam and this field is one of the most attractive fields that having an international investment, which is supported by the most recent annual report of Vietcombank Securities (Linh Nga, 2019). Also in their report, the Merge and Acquisitions contracts (M\&A) in Vietnam market were boosted approximately 167 times compared to \$61 million with 18 contracts in 2005 (Ha Thu, 2019). Compared to the first decade of the $21^{\text {st }}$ century in Vietnam, many big supermarkets and convenience stores have failed on gaining customers' loyalty and lost their markets in Vietnam such as Metro, Maximart, Fivimart, Citimart (Ha Thu, 2018). Surviving in the battle of gaining customers' trust, Saigon Coop recently celebrated its 30 -years-business and the 23 years on the foundation of Coopmart supermarket system to supply the needs of Vietnamese people on buying daily consumed products (Minh Thang, 2019; SaigonCoop, 2019). According to Saigon Coop, the main key for their success is the flexibly operating and innovating the system based on the continuously updating the market's trends and concentrating in consumers' needs (Coopmart, 2017). However, to be adapted to the world's changes earning customers' loyalty and their interests and satisfactions from commercial markets must be carefully considered. There are times 
many big corporations fail to continue their businesses smoothly or sometimes got bankrupted when fails to achieve customers' loyalty and satisfaction such as Nokia, Yahoo, United Airlines, Sony and so on (Cox \& Rodionova, 2017; Davies \& Thompson, 2014; Hof, 2012; Minds, 2018). Once again, it is important to earn customer satisfaction as well as customer's loyalty to survive the competition in the globalization era. There are times wrong decisions in a business move or failed to innovate have shown consequences to the business despite significant good reputations and customer satisfactions such as the Coca Cola, Blockbuster, and Compaq's failures (Goh, 2017; Smith, 2013). Thus, it is important to know innovation moves ensuring the catch on customer satisfactions and their loyalties guaranteeing the firms' future development, which is also the aims for Coopmart as well as the main focus of this study. In this paper, we aim to evaluate the effect of innovative activities on the consumer perceived values in addition to their satisfaction and loyalty. Moreover, this paper tries to research the addressed questions: (1) Which factors represent the corporation's innovation activities? (2) How innovation factors could affect the consumer perceived value, satisfaction, and loyalty to the corporation? Then this paper could suggest some managerial implications for enhancing innovated activities of the corporation.

\section{Literature review}

\subsection{Background theory: Resource-based view theory and innovation}

Resource-based theory is an approach to increase the competitive advantage to get firm performance by focusing on resources (Wernerfelt, 1984). Barney (1991) argues that the firm could look inside the company to find the sources of competitive advantage instead of looking at a competitive environment for it. Competitive advantage can be gained by offering clients with value, rare, inimitable, and non-substitutable, called VRIN (Eisenhardt \& Martin, 2000). Resource-based theory is expanding in the market and forms the competitive advantage and business performance of the firm. Thus, innovation is a way to maximize internal resources. By doing that, the company has increased its development in terms of business, market, and customer aspects.

According to Fontana (2011), innovation aims to make the competitive advantage of firms. In terms of competitiveness, innovation helps the firms in sustaining a pattern of continuous changes in the company and how that offering is created and delivered. Innovation is an important factor to achieve the business performance of firms, markets, and customers (Gamal, Salah, \& Elrayyes, 2011).

\subsection{Study concept}

\subsubsection{Innovation}

There are various definitions of innovation, which is recognized as a key factor for the corporations' development (Schumpeter \& Opie, 1934; Sundbo, 1997). Schumpeter and Opie (1934) defined innovation as the novel actions that combining the existing capacities to form new things include products, methods, processes, and other things that involve the economic sphere as well as commercial practice. Also, Vaccaro, Parente, and Veloso (2010) rephrased the ability that a firm can adapt to the needs of the market as the "innovation performances". In supporting the precedent views, YuSheng and Ibrahim (2019) emphasized innovation as the ability for exploring, developing, and implementing new moves for the operation of the organization. To sum up, innovation is the processes of looking for new approaches, quality boosting, and findings in both ways of process functioning as well as products for satisfying the needs of markets and gaining both customers' loyalty and perceived values, which also defines how innovation is addressed in this search. 
When classifying the categories of innovation, Burdon, Mooney, and Al-Kilidar (2015) remarked Foster and Kaplan's work on innovation's benchmarks include "Incremental innovation", "Radical innovation", and "Transformation innovation" (Burdon et al., 2015; Foster \& Kaplan, 2011). Later, 4 main dimensions that generally categorized the innovation on its specific operating fields include "Product/service innovation, process innovation, market innovation and organizational innovation" (Oecd, 2005; YuSheng \& Ibrahim, 2019). However, these dimensions recently updated where innovation is divided into "Product Innovation" and "Business Process Innovation" with 6 addressed subcategories for describing Business Process Innovation (OECD \& Eurostat, 2018). In the investigating topic, the main key factors of the problem are the incremental innovation in business process innovation with the subcategories are the updates in "marketing and sales" and part of improvements in "production of goods and service". In detail, the innovation key factors in this paper include the innovations in Marketing, Products/Services, and Social Media.

\subsubsection{Customers' satisfaction, loyalty, and consumers perceived value}

Many scholars often refer satisfaction as the degree that the customers' expectations fit with the quality and performance of the provided products/services that they received and it is marked as one of the most important core factors, the key of success, the marketing field's motto, and goal for firms' future development (E. W. Anderson \& Sullivan, 1993; Kotler \& Keller, 2003; Swan \& Oliver, 1989). It is believed that customer satisfaction will have a positive effect on repurchasing behaviors on the products or services offered by a specific provider (Chitturi, Raghunathan, \& Mahajan, 2008; Mittal \& Kamakura, 2001), which was found to be the basis proof for addressing customer's loyalty (Mittal \& Kamakura, 2001; Schneider \& Bowen, 1999), and boosting the firm's image (Hallencreutz \& Parmler, 2019; Liat, Mansori, \& Huei, 2014). The key drivers of customer satisfactions are believed as "perceived quality, perceived value, and customer expectations" (Cronin. Jr \& Taylor, 1992; Sivadas \& Baker-Prewitt, 2000) and be measured by the developed indexes reflecting "National Customer Satisfaction dimensions" in various countries (E. W. Anderson, Fornell, \& Lehmann, 1994; Fornell, Johnson, Anderson, Cha, \& Bryant, 1996). Thus, the hypotheses for investigating the positive and direct impacts of products and services related innovation, as well as consumer perceived values on customers' satisfaction are proposed, which is the level of customer's positive emotional activities toward specific products/services or branches in this context. This paper also tests the impact of customer satisfactions on their loyalty to reconfirm the positive direct impact.

Being recorded as one of the key factors for customer's innovation, consumer perceived values is addressed as the overall evaluation and consideration of consumers in the trade-offs between received benefits and costs when purchasing for a product or service, which also the definition of consumer perceived value used in this search (Lindgreen \& Wynstra, 2005; Zeithaml, 1988). The importance of consumer perceived value has been recorded many times, however, most studies address the loyalty as the result of high delighted level thanks to high perceived value without investigating the direct impact of consumer perceived value to customer's loyalty (Fornell et al., 1996; Türkyılmaz \& Özkan, 2007). Also, although there are searches about the effects of innovation on consumers' perceived value (S. J. Kim, Kim, \& Choi, 2019; Yang \& Peterson, 2004), this impact still has low attraction from scholars compared to other searches in the same field. Thus, this search aims to study the effects of consumer perceived value with innovation factors on customer loyalty, which is the insight of this research. 
Customer's loyalty is believed to have a significant tie with the customer satisfactions, which have been tested many times (Mittal \& Kamakura, 2001; Selnes, 1993), and identified as the high level in customers' preferable in repurchasing products/services compared to the firm's competitors despite the situation (Kursunluoglu, 2014; Oliver Richard, 1997). Martensen, Gronholdt, and Kristensen (2000) addressed four keys that result in the customer's loyalty include: the repurchase behavior, price's changes acceptance, high tendency level in a recommendation, and the resistance to firms' competitors' offers, which is confirmed by many scholars (Auh, Bell, McLeod, \& Shih, 2007; Fečiková, 2004). Hence, the potential value from the customer's loyalty is limitless for the firm's growth. In this context, loyalty is defined as the high level of customer's favorable in supporting a specific branch's offered products/services besides the neglect of their competitors' offers.

\subsubsection{The relationships among innovation, customers' satisfaction, loyalty, and consumers} perceived value

The relationships among innovation and factors represented for customers' purchasing habits and behaviors have been conducted many times:

Hussain (2016) found the positive impact relationships between the service quality and perceived value to customer satisfaction and brand loyalty, where both of them can be used to predict the future state of customer's brand loyalty as well as customer satisfaction. This study also implies the prediction of brand loyalty from customer satisfaction. Moreover, Hussain's service quality can be identified as our study's product/service innovation factor. Also, a strong impact between service quality and customer loyalty is addressed in the search of Liu, Lee, and Hung (2017) in both direct and indirect ways through customer satisfaction channels where customer satisfaction is believed to have a strong effect on customer's loyalty in this search.

When investigating the impacts among the perceived service quality, customer satisfaction, revisit intentions, further recommendation, and perceived advantage in re-purchasing services, Ažman and Gomišček (2015) confirmed the positive and non-linear in the direct impact relationship from the service quality to the customer satisfaction and later the customer satisfaction will impact the customer's loyalty through the repurchase habit, word-of-mouth advertisement, and revisit behavior. In addition to this, Luarn and Lin (2003) addressed a strong influence from customer satisfaction and perceived values to customer's loyalty behavior. Furthermore, YuSheng and Ibrahim (2019)'s study clarifies the tight impacts of the service innovation on customer satisfaction and the customer's loyalty.

Mahmoud, Hinson, and Anim (2018) investigated the effects between the innovation factors include concept, process, and technological system to customer value creation and customer satisfaction. The research found that two factors affect customer satisfaction by the service concept and service process, while the technological aspects were denied to have impacts on the customer satisfaction and pointed out that service innovation has significant impacts on customer satisfaction with and without customer value creation. Simon and Petnji Yaya (2012) in the study of system integration, innovation, and customer satisfaction relationships also drive a positive and direct effect from marketing innovation to customer satisfaction, while denying the impacts between a process innovation and organizational innovation to customer satisfaction. 


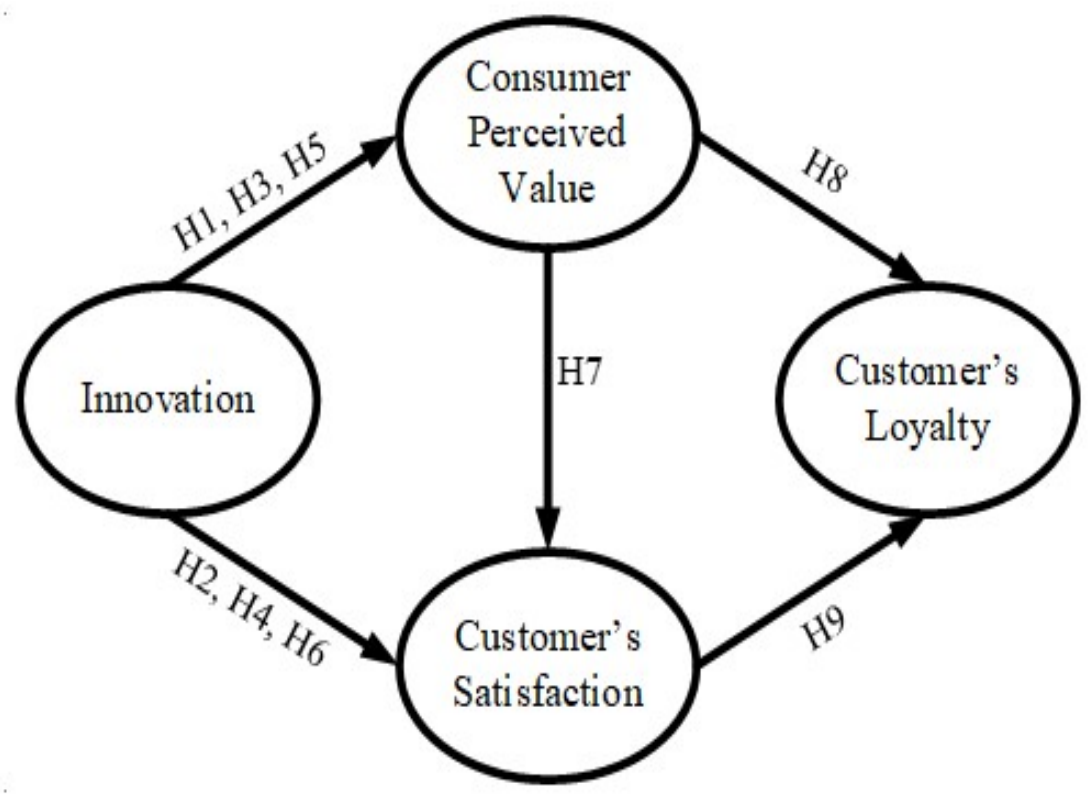

Figure 1. Proposed research model

Although many studies have been conducted before about the innovation factors, consumer perceived value, customer satisfaction, and customer's loyalty, however, the studies about the details in innovation still be an insightful search for science and there are very few searches about the impact of social media innovation to other factors. Furthermore, the impacts from innovation factors to consumer perceived value, although been researched many times, but still not be recorded as the main concern from scholars. Thus, the following hypotheses are developed in this context and its proposed model is shown in Figure 1 and listed below:

H1: Marketing innovation has a positive direct impact on consumer perceived value

H2: Marketing innovation has a positive direct impact on customer satisfactions

H3: Product innovation has a positive direct impact on consumer perceived value

H4: Product innovation has a positive direct impact on customer satisfactions

H5: Social media innovation has a positive direct impact on consumer perceived value

H6: Social media innovation has a positive direct impact on customer satisfactions

H7: Consumer perceived value has a positive direct impact on customer satisfactions

H8: Consumer perceived value has a positive direct impact on customer's loyalty

H9: Customer satisfactions has a positive direct impact on customer's loyalty

\section{Methodology}

The research was divided into two phases in which the first phase was the pilot study with qualitative analysis by face to face interview in a group within 90 minutes with 5 employees for the scale selection and validation for being suited with the retail's field of study. They are working in Coopmart system at the middle and senior management level with at least 10 years' experience as department heads, deputy heads, and managers. At first, there are 29 variables were suggested 
for the survey, which later were revised and reduced to 27 variables, and divided into 6 factors with measurement is described in Table 1 and used 5 -point Likert scales $(5=$ strongly agree; $1=$ strongly disagree). The changes were made on consumer perceived value and customer satisfaction factors. Convenient sampling was chosen to conduct the sample collected and the modified factors are shown in Table 1 and Table 4.

\section{Table 1}

Constructed table for the survey data

\begin{tabular}{|l|l|}
\hline \multicolumn{1}{|c|}{ Construct } & \multicolumn{1}{|c|}{ Measurement } \\
\hline $\begin{array}{l}\text { Marketing Innovation } \\
\text { (Zuniga-Collazos \& } \\
\text { Palacio, 2016) }\end{array}$ & $\begin{array}{l}\text { Seven items were chosen for addressing the marketing innovation } \\
\text { factor include updating in: marketing activities, brochure and } \\
\text { information, layouts for product visualizing, products on shelves, sale } \\
\text { off programs, customer's service, employees' attitudes, and service } \\
\text { abilities. }\end{array}$ \\
\hline $\begin{array}{l}\text { Products/Services } \\
\text { Innovation } \\
\text { (Daragahi, 2017) }\end{array}$ & $\begin{array}{l}\text { Three items represent for this factor include new products/services } \\
\text { release rate, time, and high-quality products/services. }\end{array}$ \\
\hline $\begin{array}{l}\text { Social Media Innovation } \\
\text { (Samydai, Yaseen, \& } \\
\text { Dajani, 2018) }\end{array}$ & $\begin{array}{l}\text { The SMI was constructed with four items: flexibility in information } \\
\text { searching; sharing information via a social network; positive } \\
\text { feedbacks and evaluations from customers to Coopmart's image and } \\
\text { service. }\end{array}$ \\
\hline $\begin{array}{l}\text { Perceived Value } \\
\text { (Yang \& Peterson, 2004) }\end{array}$ & $\begin{array}{l}\text { This factor is analyzed through four items: reliability, pricing policy, } \\
\text { and discount programs in products/services; addressing products and } \\
\text { customers' support services. }\end{array}$ \\
\hline $\begin{array}{l}\text { Customer satisfaction } \\
\text { (Weng, Ha, Wang, \& } \\
\text { Tsai, 2012) }\end{array}$ & $\begin{array}{l}\text { The customer satisfaction was computed from Coopmart offered } \\
\text { products/services on three items: general satisfaction, customers' } \\
\text { attitudes when using products/services, the meets on the customers' } \\
\text { needs. }\end{array}$ \\
\hline $\begin{array}{l}\text { Customer's Loyalty } \\
\text { (Luarn \& Lin, 2003) }\end{array}$ & $\begin{array}{l}\text { The customer's loyalty was addressed by six items: foremost choice, } \\
\text { loyalty, encouragement level, proud to be a part of Coopmart, negative } \\
\text { information resistance, rate of suggestions for future growth. }\end{array}$ \\
\hline
\end{tabular}

Source: The research's data analysis

Quantitative analysis with data collecting in both direct and indirect ways using Google Docs is the next step of this study. To ensure the confidence for the Confirmatory Factor Analysis (CFA) and Structural Equation Model (SEM) testing, a total of 300 questionnaires were distributed and 291 were returned from November 2018 to January 2019, the other 9 responses were filtered and removed due to being unqualified. The respondents are customers who hold Coopmart's member cards. 


\section{Results}

\subsection{Sample structure}

Table 2

Summarized data for statistical purpose

\begin{tabular}{|c|l|c|c|}
\hline Construct & \multicolumn{1}{|c|}{ Classification } & Number & $\mathbf{\%}$ \\
\hline \multirow{3}{*}{ Gender } & Female & 209 & 71.8 \\
\cline { 2 - 4 } & Male & 81 & 28.2 \\
\hline \multirow{4}{*}{ Age } & Below 20 years old & 40 & 13.7 \\
\cline { 2 - 4 } & $21-40$ years old & 119 & 40.9 \\
\cline { 2 - 4 } & $41-60$ years old & 93 & 32.0 \\
\cline { 2 - 4 } & $>61$ years old & 39 & 13.4 \\
\hline \multirow{5}{*}{ Education } & High school & 46 & 15.8 \\
\cline { 2 - 4 } & College & 68 & 23.4 \\
\cline { 2 - 4 } & University & 135 & 46.4 \\
\cline { 2 - 4 } & Higher Degree & 42 & 14.4 \\
\hline \multirow{5}{*}{ Major } & Office staffs & 146 & 50.2 \\
\cline { 2 - 4 } & Businessmen & 68 & 23.4 \\
\cline { 2 - 4 } & Manufacturer & 36 & 12.4 \\
\cline { 2 - 4 } & Others & 41 & 14.1 \\
\hline
\end{tabular}

Source: Data analysis result of the research

From the statistics, the majority of respondents are females who account for over 70 percent of the survey, where approximately 75 percent of Coopmart loyal customers with ages ranging from 21 to 60 . Moreover, the total rate of college and university degree holders accumulate for over 70 percent while in the major classification, the total rate of office staff and businessmen are close to 75 percent.

\subsection{Confirmatory Factor Analysis (CFA)}

A CFA test was applied to the sample data using AMOS to test the reliability and validity of the model's variables, where all measurement items are accepted for further tests. As shown in Table 3, CMIN $/ d f=1.173$, the root mean square error of approximation (RMSEA) $=0.024$ that lower than 0.08 , along with the comparative fit index (CFI), the normed fit index (NFI), the goodness of fit index (GFI), which were all higher than 0.90 , illustrating acceptable model fit (Hu $\&$ Bentler, 1999). The model's internal consistency was tested via the variables' reliability measured by Cronbach's $\alpha$ and composite reliability measures, which is recommended that these values should higher than the acceptable level of 0.7 (Joreskog, 1971). Two standards were used to assess the convergent as well as the discriminant validity of the model include (1) average variance extracted (AVE) and (2) indicator factor loadings (J. C. Anderson \& Gerbing, 1988; Fornell \& Larcker, 1981). 
Table 3

CFA test results (Retrieved from AMOS)

\begin{tabular}{|c|c|c|c|c|c|c|}
\hline$\chi^{\mathbf{2}}$ & $\boldsymbol{d} \boldsymbol{f}$ & $\mathbf{C M I N} / \boldsymbol{d} \boldsymbol{f}$ & GFI & CFI & TLI & RMSEA \\
\hline 362.457 & 309 & 1.173 & 0.918 & 0.986 & 0.984 & 0.024 \\
\hline
\end{tabular}

Source: Data analysis result of the research

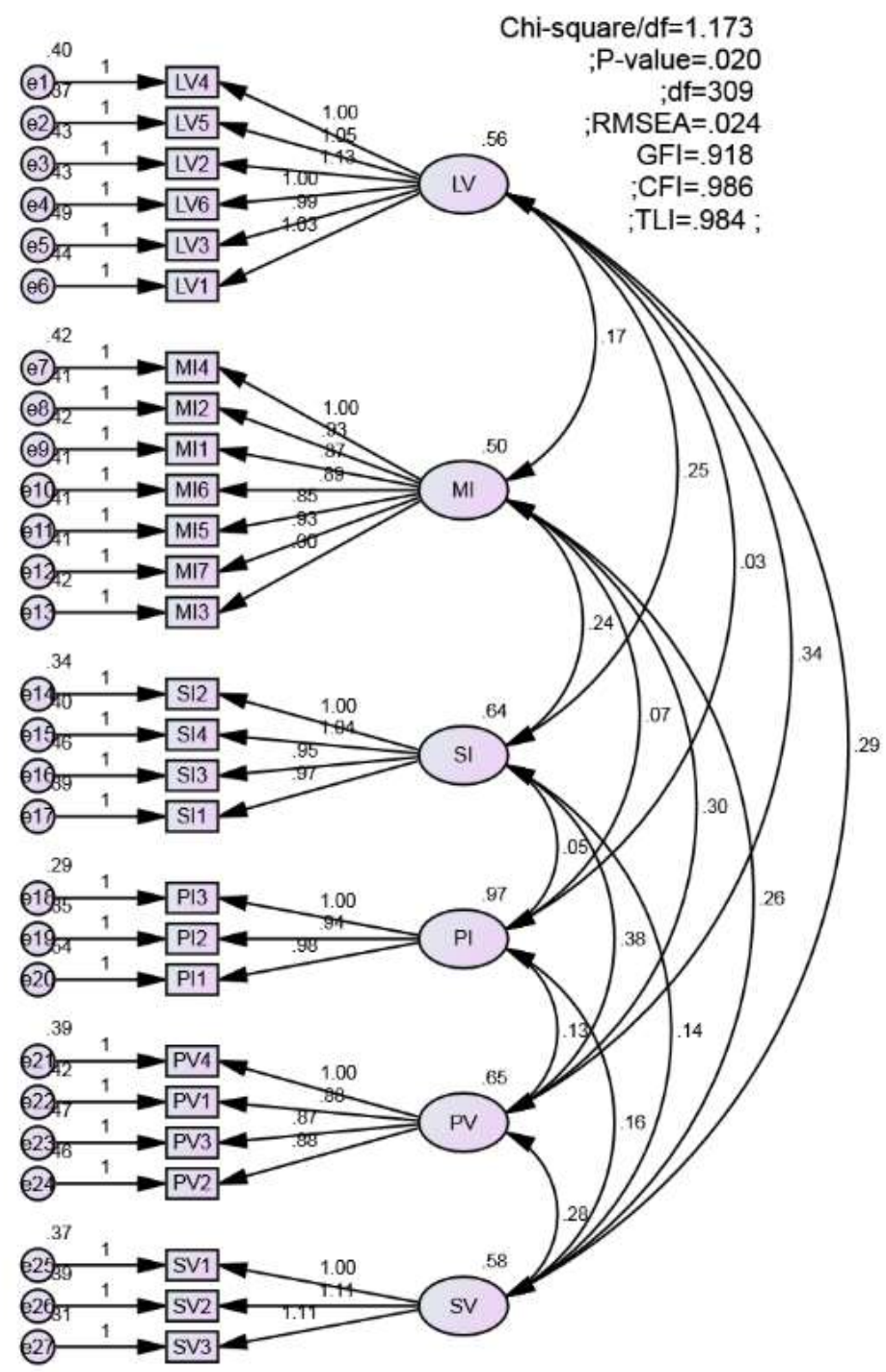

Figure 2. CFA model test result (Retrieved from AMOS)

For the convergent validity standard, where each variable should exceed 0.5 , the computed results have proven to be satisfied with further tests in Table 4 and Figure 2. Also, the computed confidence interval (varies from 0.911 to 0.945 ) indicates the discriminant validity in two ways: firstly, there is no value of 1 within parameters shows the discriminant validity for all variables, and secondly, the correlation coefficients in each column are lower than the square roots of the AVE values proves the discriminant validity for each variable (Fornell \& Larcker, 1981). Also, the p-value computed from AMOS is lower than 0.05 proves the validity of the model for the structural equation modeling (SEM) test. 


\section{Table 4}

Cronbach Alpha, composite reliability, and average variance extracted test result (Retrieved from AMOS)

\begin{tabular}{|c|c|c|}
\hline Latent and observed variables & Mean & $\begin{array}{l}\text { Factor } \\
\text { Loadings }\end{array}$ \\
\hline \multicolumn{3}{|c|}{$\begin{array}{c}\text { Marketing Innovation (MI) } \mathrm{CR}=0.993 \mathrm{AVE}=0.956 \alpha=0.876 \text { Mean }=4.194 \\
\text { (Zuñiga-Collazos \& Palacio, 2016) }\end{array}$} \\
\hline $\begin{array}{l}\text { MI 01. Coopmart has innovated many activities in marketing to be } \\
\text { attracted and get closed to customers }\end{array}$ & 4.223 & 0.932 \\
\hline $\begin{array}{l}\text { MI 02. The brochures and information about Coopmart always be } \\
\text { innovated }\end{array}$ & 4.179 & 1.000 \\
\hline $\begin{array}{l}\text { MI 03. The layouts for products visualizing are frequently and suitably } \\
\text { designed and innovated. }\end{array}$ & 4.199 & 0.967 \\
\hline MI 04. Products on selves are innovated. & 4.124 & 1.073 \\
\hline MI 05. Co.opmart has many attractive discounts programs for customers. & 4.199 & 0.915 \\
\hline $\begin{array}{l}\text { MI 06. Coopmart customer's services (checkout, delivery, and reserving) } \\
\text { always be innovated. }\end{array}$ & 4.206 & 0.948 \\
\hline $\begin{array}{l}\text { MI 07. Coopmart employees' attitudes and servicing abilities are } \\
\text { innovated to catch customers' needs. }\end{array}$ & 4.227 & 1.000 \\
\hline \multicolumn{3}{|c|}{$\begin{array}{l}\text { Products/Services Innovation (PI) } \mathrm{CR}=1.010 \mathrm{AVE}=1.064 \alpha=0.876 \mathrm{Mean}=4.024 \\
\text { (Daragahi, 2017) }\end{array}$} \\
\hline $\begin{array}{l}\text { PI 01. Coopmart's new products/services releasing rates faster than } \\
\text { other supermarket branches. }\end{array}$ & 3.959 & 1.043 \\
\hline PI 02. Coopmart releases new products/services at the right times. & 4.045 & 1.000 \\
\hline PI 03. Coopmart has many high-quality new products/services. & 4.069 & 1.056 \\
\hline \multicolumn{3}{|c|}{$\begin{array}{c}\text { Social Media Innovation (SI) CR }=1.010 \mathrm{AVE}=1.042 \alpha=0.862 \text { Mean }=4.105 \\
\text { (Samydai et al., 2018) }\end{array}$} \\
\hline SI 01. Coopmart's information is easy to be found on the Internet. & 4.127 & 1.000 \\
\hline SI 02. Coopmart's information is shared in social networks. & 4.103 & 1.028 \\
\hline $\begin{array}{l}\text { SI 03. Most customers have positive feedbacks on social networks after } \\
\text { using the Coopmart's services. }\end{array}$ & 4.110 & 0.980 \\
\hline $\begin{array}{l}\text { SI 04. Coopmart's images continuously have more and more positive } \\
\text { evaluations from customers. }\end{array}$ & 4.079 & 1.072 \\
\hline \multicolumn{3}{|c|}{$\begin{array}{c}\text { Perceived Value }(\mathrm{PV}) \mathrm{CR}=1.023 \mathrm{AVE}=1.097 \alpha=0.830 \text { Mean }=4.143 \\
(\text { Yang \& Peterson, 2004) }\end{array}$} \\
\hline PV 01. The products/services offered by Coopmart are trustworthy. & 4.175 & 1.017 \\
\hline $\begin{array}{l}\text { PV 02. The prices of products/services offered by Coopmart are } \\
\text { acceptable. }\end{array}$ & 4.120 & 1.014 \\
\hline
\end{tabular}




\begin{tabular}{|c|c|c|}
\hline Latent and observed variables & Mean & $\begin{array}{l}\text { Factor } \\
\text { Loadings }\end{array}$ \\
\hline $\begin{array}{l}\text { PV 03. Coopmart always has many promotions and discounts programs } \\
\text { for their products/services. }\end{array}$ & 4.179 & 1.000 \\
\hline $\begin{array}{l}\text { PV 04. It is easy to search for the products in Coopmart, the fast checkout } \\
\text { and delivery services, and many additional support services. }\end{array}$ & 4.096 & 1.152 \\
\hline \multicolumn{3}{|c|}{$\begin{array}{c}\text { Customer satisfactions (SV) } \mathrm{CR}=1.047 \mathrm{AVE}=1.156 \alpha=0.849 \text { Mean }=4.087 \\
\text { (Weng et al., 2012) }\end{array}$} \\
\hline SV 01. I'm satisfied with the Coopmart products/services. & 4.069 & 1.000 \\
\hline SV 02. I like using the Coopmart products/services. & 4.110 & 1.114 \\
\hline SV 03. The Coopmart products/services have caught my expectations. & 4.082 & 1.108 \\
\hline \multicolumn{3}{|c|}{$\begin{array}{c}\text { Customer's Loyalty (LV) } \mathrm{CR}=1.022 \mathrm{AVE}=1.068 \alpha=0.893 \text { Mean }=4.102 \\
\text { (Luarn \& Lin, 2003) }\end{array}$} \\
\hline LV 01. Coopmart has always been my foremost choice. & 4.045 & 1.029 \\
\hline LV 02. I'm loyal to Coopmart. & 4.069 & 1.123 \\
\hline $\begin{array}{l}\text { LV 03.I announce to other customers about my experiences with } \\
\text { Coopmart. }\end{array}$ & 4.079 & 0.990 \\
\hline LV 04. I am proud to be a significant part of Coopmart's grant family. & 4.124 & 1.000 \\
\hline $\begin{array}{l}\text { LV 05. I will protect Coopmart when seeing negative information about } \\
\text { the Coopmart. }\end{array}$ & 4.175 & 1.045 \\
\hline $\begin{array}{l}\text { LV 06. I usually give comments on Coopmart's improvement in } \\
\text { products/services and the firms' developments. }\end{array}$ & 4.120 & 0.997 \\
\hline
\end{tabular}

Source: Data analysis result of the research

Table 5

Discriminant validity

\begin{tabular}{|c|c|c|c|c|c|c|}
\hline & MI & PI & SI & PV & SV & $\mathbf{L V}$ \\
\hline MI & 0.936 & & & & & \\
\hline PI & 0.092 & 0.936 & & & & \\
\hline SI & 0.372 & 0.069 & 0.928 & & & \\
\hline PV & 0.448 & 0.152 & 0.509 & 0.911 & & \\
\hline SV & 0.416 & 0.184 & 0.200 & 0.380 & 0.921 & \\
\hline LV & 0.292 & 0.048 & 0.365 & 0.482 & 0.439 & 0.945 \\
\hline
\end{tabular}

Source: Data analysis result of the research

Note. Diagonal elements in the correlation matrix of constructs are the square root of the AVE values; the discriminant validity presents when the diagonal elements are greater than the off-diagonal elements 


\subsection{Structural Equation Modelling (SEM)}

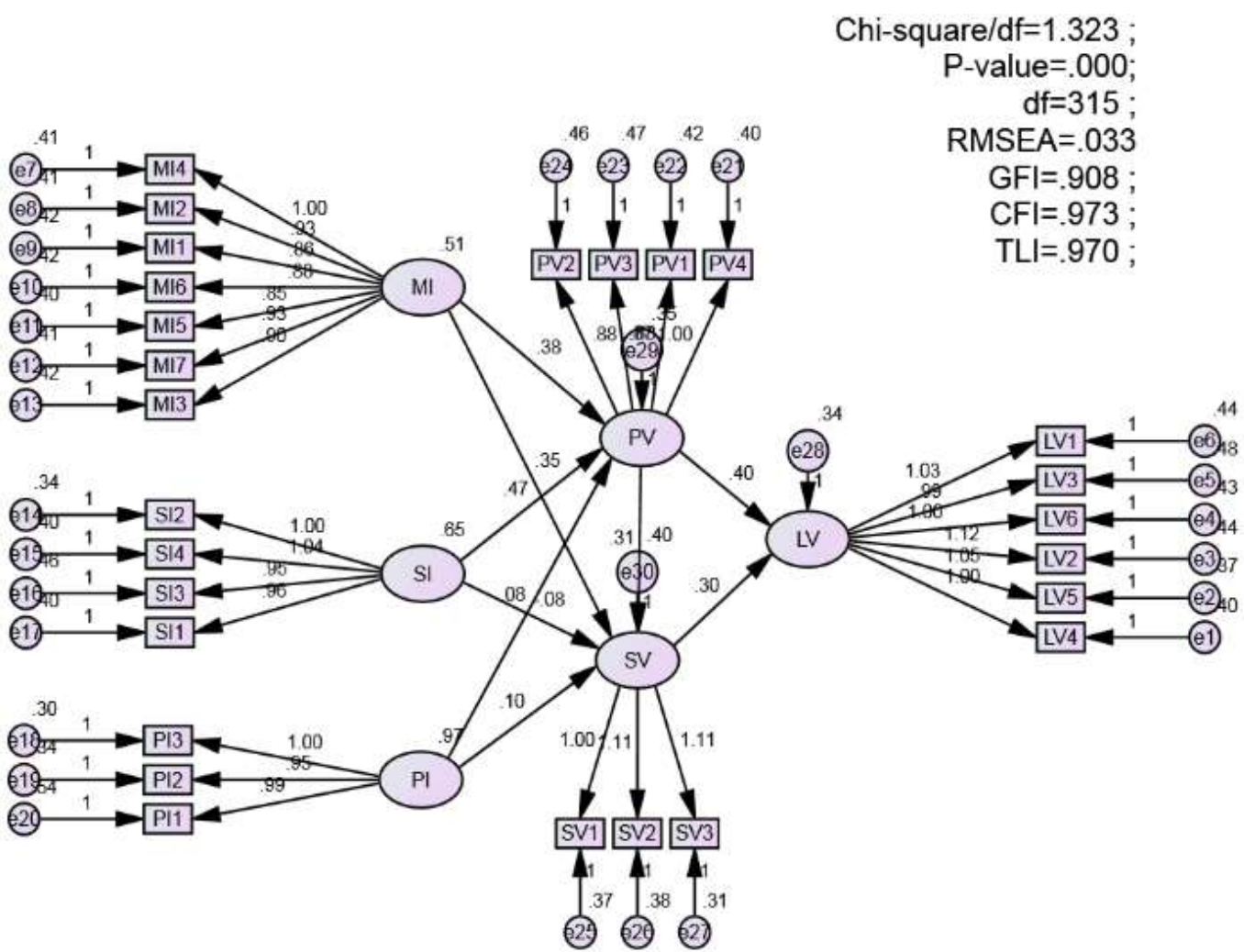

Figure 3. SEM model test result (Retrieved from AMOS)

According to the suggestion from (Hair, Black, Babin, \& Anderson, 2018), all the calculated outcomes have satisfied the theoretical requirements, in which CMIN/df $=1.189<2$; all GFI, CFI, and TLI calculated outcomes are higher than 0.9 and RMSEA $=0.026<0.05$. Thus the proposed SEM model is suitable for the collected survey data.

\section{Table 6}

SEM test results (Retrieved from AMOS)

\begin{tabular}{|c|c|c|c|c|c|c|}
\hline $\boldsymbol{\chi}^{\mathbf{2}}$ & $\boldsymbol{d} \boldsymbol{f}$ & $\mathrm{CMIN} / \boldsymbol{d} \boldsymbol{f}$ & GFI & CFI & TLI & RMSEA \\
\hline 370.968 & 312 & 1.189 & 0.916 & 0.985 & 0.983 & 0.026 \\
\hline
\end{tabular}

Source: Data analysis result of the research

All 6 factors are tested in the SEM Model and have shown significant moves that reject the impacts of product/service innovation factor to the consumer perceived value and the social media innovation factor to the customer satisfaction at a 95\% confidence interval. The test result also denies the impact of product/service innovation to customer satisfaction at a $99 \%$ confidence interval while supports the proposed fact at a $95 \%$ confidence interval. 
Table 7

Correlation test results (Retrieved from AMOS)

\begin{tabular}{|c|c|c|c|c|c|}
\hline Correlations & $\begin{array}{c}\text { Standardized } \\
\text { Estimate }\end{array}$ & Estimate & $\begin{array}{c}\text { Standard } \\
\text { Error }\end{array}$ & Critical Ratio & P-Value \\
\hline $\mathrm{PV} \leftarrow \mathrm{MI}$ & 0.315 & 0.332 & 0.072 & 4.603 & $* * *$ \\
\hline $\mathrm{PV} \leftarrow \mathrm{PI}$ & 0.093 & 0.07 & 0.042 & 1.659 & 0.097 \\
\hline $\mathrm{PV} \leftarrow \mathrm{SI}$ & 0.462 & 0.415 & 0.065 & 6.386 & $* * *$ \\
\hline $\mathrm{SV} \leftarrow \mathrm{MI}$ & 0.344 & 0.395 & 0.09 & 4.384 & $* * *$ \\
\hline $\mathrm{SV} \leftarrow \mathrm{PI}$ & 0.126 & 0.103 & 0.05 & 2.074 & 0.038 \\
\hline $\mathrm{SV} \leftarrow \mathrm{SI}$ & -0.111 & -0.109 & 0.081 & -1.344 & 0.179 \\
\hline $\mathrm{SV} \leftarrow \mathrm{PV}$ & 0.329 & 0.358 & 0.103 & 3.465 & $* * *$ \\
\hline $\mathrm{LV} \leftarrow \mathrm{PV}$ & 0.426 & 0.457 & 0.079 & 5.799 & $* * *$ \\
\hline $\mathrm{LV} \leftarrow \mathrm{SV}$ & 0.306 & 0.302 & 0.068 & 4.446 & $* * *$ \\
\hline
\end{tabular}

Source: Data analysis result of the research

Table 8 summaries the outcome of the retrieved SEM test results from AMOS.

Table 8

Hypotheses' conclusion

\begin{tabular}{|c|l|c|}
\hline Hypothesis & \multicolumn{1}{|c|}{ States } & Results \\
\hline H1 & $\begin{array}{l}\text { Marketing innovation has a positive direct impact on consumer } \\
\text { perceived value }\end{array}$ & Accept \\
\hline H2 & $\begin{array}{l}\text { Marketing innovation has a positive direct impact on customer } \\
\text { satisfactions }\end{array}$ & Accept \\
\hline H3 & $\begin{array}{l}\text { Product innovation has a positive direct impact on consumer } \\
\text { perceived value }\end{array}$ & $\begin{array}{l}\text { Reject at } \\
95 \% \text { C.I. }\end{array}$ \\
\hline H4 & $\begin{array}{l}\text { Product innovation has a positive direct impact on customer } \\
\text { satisfactions }\end{array}$ & Accept \\
\hline H5 & $\begin{array}{l}\text { Social media innovation has a positive direct impact on consumer } \\
\text { perceived value }\end{array}$ & Accept \\
\hline H6 & $\begin{array}{l}\text { Social media innovation has a positive direct impact on customer } \\
\text { satisfactions }\end{array}$ & $\begin{array}{l}\text { Reject at } \\
95 \% \text { C.I. }\end{array}$ \\
\hline H7 & $\begin{array}{l}\text { Consumer perceived value has a positive direct impact on customer } \\
\text { satisfactions }\end{array}$ & Accept \\
\hline H8 & $\begin{array}{l}\text { Consumer perceived value has a positive direct impact on customer's } \\
\text { loyalty }\end{array}$ & Accept \\
\hline H9 & $\begin{array}{l}\text { Customer satisfactions has a positive direct impact on customer's } \\
\text { loyalty }\end{array}$ & Accept \\
\hline
\end{tabular}




\section{Discussion}

After all, at 95\% confidence interval, marketing innovation has proven to have a positive direct impact on consumer perceived value and customer satisfaction with the regression coefficients is 0.315 and 0.344 respectively proves the stays of $\mathbf{H 1}$ and H2: the increase in marketing innovated activities will enhance the consumer perceived value and customer satisfactions which is supported by Zuñiga-Collazos' study.

Also, the p-value for the product innovation's impact on consumer perceived value is 0.097 welcomes the hypothesis $\mathrm{H3}$ at $\mathbf{9 0 \%}$ confidence interval and refuses to accept it at higher confidence level, for example, $95 \%$ confidence interval, which is why we reject this hypothesis in our conclusion which is opposed by the studies of Daragahi (2017) and Naveed, Akhtar, and Cheema (2013). However, product innovation has a slight positive direct impact to the customer's perceived value with the regression coefficient is 0.093 while this factor impacts the customer satisfactions confirms the existence of hypothesis H4, with the regression coefficient is 0.126 .

In addition to this, hypothesis H5 supports the findings in the research of Samydai et al. (2018), a positive direct impact on consumer perceived value has been found in the social media innovation with a regression coefficient at 0.462 but hypothesis $\mathrm{H6}$ was rejected in the SEM test in the $95 \%$ confidence interval since the p-value is higher than $5 \%$ which shows that there are no relationships between social media innovation and customer satisfaction.

Moreover, both hypotheses $\mathrm{H7}$ and $\mathrm{H8}$ were admitted in the research under the regression coefficient at 0.329 and 0.426 respectively proving there is a positive direct impact on customer satisfaction and customer loyalty from the consumer perceived value. In addition to this, H9 is accepted with the regression coefficient is 0.306 , which is supported by the findings of Luarn and Lin (2003), and Y. H. Kim, Kim, and Wachter (2013).

Besides, taking look back to the hypotheses tests results in Table 7, it can also be seen that both the relationships of the products/services innovation with consumer perceived value and customer satisfaction are rejected at $99 \%$ confidence interval, while only the tie between social media innovation and customer satisfaction is rejected at the same confidence interval and there are no rejects on the link between marketing innovation with customer's attitudes towards the purchased products/services. This proving the ranks in the impacts of the innovation factors mean scores, where the marketing innovation will have a tight bone with customer's behaviors with the mean scores is 4.194 , the social media innovation then has the moderate effect to customer's attitudes with the mean scores is 4.105 , and the products/service innovation with the mean scores is 4.024 , have the least connection to customer's thoughts toward the purchased products/services and firms' characteristics. It can also be drawn from Tables 4, 5, and 7 that high consumer perceived value will result in higher chances to earn loyalty from the customers than customer satisfaction. This can also be seen in the ranks of mean scores between these factors, where the consumer perceived value takes the first place with 4.143 , the second place is occupied by the customer's loyalty with 4.102, and finally is customer satisfaction with 4.087 . This once repeats the outcome of the study that to boost the loyalty of customers, firms should aim for creating higher consumer perceived value and focus on innovating the marketing strategies rather than concentrating on creating new products/services. Social media channels can be the tools to uplift the consumer perceived value, which later result in better customer satisfaction and loyalty.

Furthermore, it can be expected the different outcomes between product innovation and consumer perceived value could come from the difference in definition between "Products" and 
"Services". Consequently, this can be an interesting field for future studies. The non-impact between social media innovation and customer satisfaction can be explained with the satisfaction that comes from the real experience and the pre-experience and post-experience comparing. The expansion of social media has boosted the customers' pre-experience feelings which fails to match their expectations after purchasing the products/services and causes the big gap between social media marketing and customer satisfaction.

\section{Recommendations for firms' developments:}

Apart from the study's outcomes, the following recommendations can be drawn:

\section{The boosting of marketing innovation activities for higher consumer perceived value and customer satisfaction}

The marketing impacts are the main key for most future developments of the firm from running new products to searching for the market and ways of distributing them. Thus, consumer perceived value and customer satisfaction were highly affected by marketing innovation. In the current state of Vietnam market, the uses of technologies in customers are dramatically climbed up, thus innovation in marketing must change to adapt to this. The rise of the globalization era has led to the interests of foreign investors in searching for new markets and expanding their reputations along with businesses. Thus, refusing to innovate based on the beliefs of customers' loyalty is not a good option. By applying more and more investments in technologies and marketing ways, the survival chances for domestic retailers and service providers can be boosted for market occupation in the future.

\section{The enhancement of products innovative activities for higher customer satisfaction}

In a world of dynamic changes by seconds, continuing to attract customer's concerns and boosting their satisfaction are the main keys for the survival of the firms due to the positive effects between customers' satisfaction and loyalties (Mittal \& Kamakura, 2001; Selnes, 1993). Thus, firms should carefully consider on continuously improving products/services to not only catch the world's trends but also get close to the customers, who always want better quality products/services at lower prices. Moreover, keep improving and innovating products/services will help enhance the customers' satisfaction that consequently lead to the customers' loyalties and helps firm expanding their business as well as cost reduction in the marketing, advertising, and operating process (Liat et al., 2014).

\section{The increasing on social media innovation activities for higher consumer perceived value}

In the development of corporations, the social media channel plays an important role in advertising and promoting the value of the corporation and tighter the business-customer relationship. Moreover, the information delivered to customers must be accurate, trustworthy, and truthful. Communications between corporate staff and customers also affect the reputation of the business, showing through the proper attitudes, politeness, friendliness, as well as willingness to help customers at any time of the employees. Disrespect attitudes or negative behaviors will significantly damage the image of the firm, and in many cases, cause customers to turn their back to the brand. Therefore, administrators need to inform their employees in the firm about communicating policies in a professional way and prioritize the customers' satisfaction first, especially the employees who continuously and frequently contact with customers.

The core element of the brand is the products/services quality of the business. But once the quality products/services are released, advertising and letting customers know about them is 
compulsory which confirms the importance of social media marketing: informing the company's updates to the customers as well as forming a seed of attraction for future merchandise activities. As a result, the corporation must boost its relationships with the advertising channels with honest information about their businesses and products which closes the gap from them to their customers under widespread advertisements and boosts the corporation's image later. To sum up, social media and business connections must be tight for significant enhancements in the future. Without social media marketing, it is difficult to build and promote the reputations of the brand.

\section{Conclusion}

\subsection{Summary of the research}

This research built a model investigating the effects of innovating activities on the customer's loyalty through consumer perceived value and customer satisfaction channels. The qualitative pilot study and quantitative analysis were applied in which a questionnaire with 6 factors along with 27 variables for the quantitative analysis was achieved from the pilot study. 300 questionnaires were distributed but only 291 questionnaires were qualified for data analysis. It was found in the study that at $95 \%$ confidence interval, product/service innovation has no impact on consumer perceived value and customer satisfaction is not affected by the social media innovation while other hypotheses were accepted and confirmed at the same confidence interval level.

\subsection{Theoretical contribution}

This study investigates the effects of innovation on other factors, in which customer's loyalty is indirectly affected through customer satisfaction and consumer perceived value channels. The relationship between innovation factors and customers' behavioral factors is that this study's main contribution and different innovation types will affect customers' behaviors in different ways has been confirmed. Thus, innovation must be carefully identified when searching its impacts on customers' psychological characteristics such as loyalty, satisfaction, and perceived value.

\subsection{Managerial implications}

This study has suggested some innovation moves should be made for the development of Coopmart retailer chains in the future in which marketing innovation should be prioritized first for achieving both customer satisfaction and consumer perceived value.

\subsection{Limitations}

Although this research has drawn out some positive results, however, it only focuses on Coopmart's customers with member cards in Ho Chi Minh City and not generalize the research outcomes. Further searches with Coopmart's branches in many big cities in Vietnam for all customers who pay for the services/products they received from Coopmart would help generalize and make the outcomes more significant in the future.

\section{References}

Anderson, E. W., Fornell, C., \& Lehmann, D. R. (1994). Customer satisfaction, market share, and profitability: Findings from Sweden. Journal of Marketing, 58(3), 53-66. doi:10.2307/1252310

Anderson, J. C., \& Gerbing, D. W. (1988). Structural equation modeling in practice: A review and recommended two-step approach. Psychological Bulletin, 103(3), 411-423. doi:10.1037/0033-2909.103.3.411 
Anderson, E. W., \& Sullivan, M. W. (1993). The antecedents and consequences of customer satisfaction for firms. Marketing Science, 12(2), 125-143. doi:10.1287/mksc.12.2.125

Auh, S., Bell, S. J., McLeod, C. S., \& Shih, E. (2007). Co-production and customer loyalty in financial services. Journal of Retailing, 83(3), 359-370. doi:10.1016/j.jretai.2007.03.001

Ažman, S., \& Gomišček, B. (2015). Functional form of connections between perceived service quality, customer satisfaction and customer loyalty in the automotive servicing industry. Total Quality Management \& Business Excellence, 26(7/8), 888-904. doi:10.1080/14783363.2014.909172

Barney, J. (1991). Firm resources and sustained competitive advantage. Journal of Management, 17(1), 99-120. doi:10.1177/014920639101700108

Burdon, S., Mooney, G. R., \& Al-Kilidar, H. (2015). Navigating service sector innovation using co-creation partnerships. Journal of Service Theory and Practice, 25(3), 285-303. doi:10.1108/JSTP-08-2013-0164

Chitturi, R., Raghunathan, R., \& Mahajan, V. (2008). Delight by design: The role of hedonic versus utilitarian benefits. Journal of Marketing, 72(3), 48-63. doi:10.1509/jmkg.72.3.48

Coopmart. (2017). Hệ thống Co.opmart cả nước đồng loạt kỷ niệm 21 năm gắn kết sản xuất và tiêu dùng trong nước [The Coop.mart system celebrates its 21 years in connecting local production and consumption]. Retrieved July 15, 2019, from http://www.coopmart.com.vn/trangchu/TinCoopmart/he-thong-coopmart-ca-nuoc-dong-loat-ky-niem-21nam-gan-ket-san-xuat-va-tieu-dung-trong-nuoc_2606.html

Cox, J., \& Rodionova, Z. (2017). United Airlines suffers near \$1bn loss in value after passenger was violently dragged off overbooked flight. Retrieved July 16, 2019, from https://www.independent.co.uk/news/business/news/united-airlines-unitedcontinental-shares-slide-drop-expect-passenger-dragged-flight-3411-overbookeda7678051.html

Cronin. J. J., Jr., \& Taylor, S. (1992). Measuring service quality - A reexamination and extension. Journal of Marketing, 56(3), 55-68. doi:10.2307/1252296

Daragahi, G. (2017). The impact of innovation on customer satisfaction: A study of the cosmetics producer in Tehran. International Review, 2017(1/2), 121-132.

Davies, P., \& Thompson, J. (2014). Sony closes in on sale of Vaio PC division. Retrieved July 17 , 2019, from https://www.ft.com/content/2ee4471c-8e34-11e3-b6f1-00144feab7de

Eisenhardt, K. M., \& Martin, J. A. (2000). Dynamic capabilities: What are they? Strategic Management Journal, 21(10/11), 1105-1121. doi:10.1002/1097-0266(200010/11)21:10/ $11<1105::$ aid-smj133>3.0.co;2-e

Fečiková, I. (2004). An index method for measurement of customer satisfaction. The TQM Magazine, 16(1), 57-66. doi:10.1108/09544780410511498

Fontana, A. (2011). Innovate we can! Innovation management and value creation revision edition. Bekasi, Malaysia: Publisher of Cipta Innovasi Sejahtera.

Fornell, C., Johnson, M. D., Anderson, E. W., Cha, J., \& Bryant, B. E. (1996). The American customer satisfaction index: Nature, purpose, and findings. Journal of Marketing, 60(4), 718. doi:10.1177/002224299606000403

Fornell, C., \& Larcker, D. F. (1981). Evaluating structural equation models with unobservable variables and measurement error. Journal of Marketing Research, 18(1), 39-50. doi: $10.2307 / 3151312$ 
Foster, R., \& Kaplan, S. (2011). Creative destruction: Why companies that are built to last underperform the market - and how to success fully transform them. New York, NY: Crown Business.

Gamal, D., Salah, E. T., \& Elrayyes, E. N. (2011). How to measure organization innovativeness. Cairo, Egypt: Technology Innovation and Entrepreneurship Center.

Goh, F. (2017). 10 companies that failed to innovate, resulting in business failure. Retrieved July 18, 2019, from https://www.collectivecampus.io/blog/10-companies-that-were-too-slow-torespond-to-change

Ha Thu (2018). Tại sao đa phần siêu thị lố, cưa hàng tiện ích càng lỗ mà doanh nghiệp vẫn "đâm đầu" vào thị trường bán lé? [Why most of supermarkets meet capital loss, convenient stores have more losses but business enterprises still invest in retail markets?] . Retrieved July 19, 2019, from http://cafef.vn/tai-sao-da-phan-sieu-thi-lo-cua-hang-tien-ich-cang-lo-ma-doanhnghiep-van-dam-dau-vao-thi-truong-ban-le-20181219160955182.chn

Ha Thu (2019). Cuộc chơi bán lẻ năm 2019 sẽ nhu thế nào? [How will the retail competition become in 2019?]. Retrieved July 20, 2019, from https://thitruong.nld.com.vn/thitruong/cuoc-choi-ban-le-nam-2019-se-nhu-the-nao-20190105121600799.htm

Hair, J. F., Black, W. C., Babin, B. J., \& Anderson, R. E. (2018). Multivariate data analysis. London, UK: Cengage Learning EMEA.

Hallencreutz, J., \& Parmler, J. (2019). Important drivers for customer satisfaction-from product focus to image and service quality. Total Quality Management \& Business Excellence, 32(5/6), 1-10. doi:1080/14783363.2019.1594756

Hof, R. (2012). Who killed Yahoo? Retrieved July 21, 2019, from https://www.forbes.com/sites/ roberthof/2012/04/17/who-killed-yahoo/\#2965257068d3

Hu, L. T., \& Bentler, P. M. (1999). Cutoff criteria for fit indexes in covariance structure analysis: Conventional criteria versus new alternatives. Structural Equation Modeling: A Multidisciplinary Journal, 6(1), 1-55. doi:10.1080/10705519909540118

Hussain, R. (2016). The mediating role of customer satisfaction: Evidence from the airline industry. Asia Pacific Journal of Marketing and Logistics, 28(2), 234-255. doi:10.1108/APJML-01-2015-0001

Joreskog, K. G. (1971). Simultaneous factor analysis in several populations. Psychometrika, 36(4), 409-426. doi:10.1007/BF02291366

Kim, S. J., Kim, K. H., \& Choi, J. (2019). The role of design innovation in understanding purchase behavior of augmented products. Journal of Business Research, 99, 354-362. doi:10.1016/j.jbusres.2017.09.047

Kim, Y. H., Kim, D., \& Wachter, K. (2013). A study of mobile user engagement (MoEN): Engagement motivations, perceived value, satisfaction, and continued engagement intention. Decision Support System, 56, 361-370. doi:10.1016/j.dss.2013.07.002

Kotler, P., \& Keller, K. L. (2003). Marketing management (11th ed.). Upper Saddle River, NJ: Prentice-Hall.

Kursunluoglu, E. (2014). Shopping centre customer service: Creating customer satisfaction and loyalty. Marketing Intelligence \& Planning, 32(4), 528-548. doi:10.1108/MIP-11-20120134

Liat, C. B., Mansori, S., \& Huei, C. T. (2014). The associations between service quality, corporate image, customer satisfaction, and loyalty: Evidence from the Malaysian hotel industry. 
Journal of Hospitality Marketing \& Management, 23(3), 314-326. doi:10.1080/19368623.2013.796867

Lindgreen, A., \& Wynstra, F. (2005). Value in business markets: What do we know? Where are $\begin{array}{llll}\text { we } \quad \text { going? } & \text { Industrial Marketing }\end{array}$ doi:10.1016/j.indmarman.2005.01.001

Linh Nga (2019). M\&A bán lẻ tiếp tục tăng và sụ lên ngôi của doanh nghiệp Việt [M\&A in retail continuously increase and the development of Vietnamese corporation]. Retrieved July 22, 2019, from http://enternews.vn/m-a-ban-le-tiep-tuc-tang-va-su-len-ngoi-cua-doanh-nghiep-viet147846.html

Liu, W. K., Lee, Y. S., \& Hung, L. M. (2017). The interrelationships among service quality, customer satisfaction, and customer loyalty: Examination of the fast-food industry. Journal of Foodservice Business Research, 20(2), 146-162. doi:10.1080/15378020.2016.1201644

Luarn, P., \& Lin, H. H. (2003). A customer loyalty model for e-service context. Journal of Electronic Commerce Research, 4(4), 156-167.

Mahmoud, M. A., Hinson, R. E., \& Anim, P. A. (2018). Service innovation and customer satisfaction: The role of customer value creation. European Journal of Innovation Management, 21(3), 402-422. doi:10.1108/EJIM-09-2017-0117

Martensen, A., Gronholdt, L., \& Kristensen, K. (2000). The drivers of customer satisfaction and loyalty: Cross-industry findings from Denmark. Total Quality Management, 11(4/6), 544553. doi:10.1080/09544120050007878

Minds, B. (2018). Why did Nokia fail and what can you learn from it? Retrieved July 23, 2019, from https://medium.com/multiplier-magazine/why-did-nokia-fail-81110d981787

Minh Thang (2019). Tung bùng giải quần vợt kỷ niệm 30 năm của SaiGon Co.Op [The jubilant tennis contest celebrating the 30 years foundation of Saigon Co.Op]. Retrieved July 24, 2019, from https://thethao.thanhnien.vn/quan-vot/tung-bung-giai-quan-vot-ky-niem-30nam-cua-saigon-coop-100657.html

Mittal, V., \& Kamakura, W. A. (2001). Satisfaction, repurchase intent, and repurchase behavior: Investigating the moderating effect of customer characteristics. Journal of Marketing Research, 38(1), 131-142. doi:10.1509/jmkr.38.1.131.18832

Naveed, T., Akhtar, I., \& Cheema, K. U. R. (2013). The impact of innovation on customer satisfaction and brand loyalty: A study of the students of Faisalabad. International Journal of Management \& Organizational Studies, 2(2), 62-68.

OECD, \& Eurostat. (2005). Oslo manual: Guidelines for collecting and interpreting innovation data (3rd ed.). Paris, France: The Measurement of Scientific and Technological Activities, OECD Publishing. doi:10.1787/9789264013100-en

OECD, \& Eurostat. (2018). Oslo manual 2018: Guidelines for collecting, reporting and using data on innovation (4th ed.). Paris, France: The Measurement of Scientific, Technological and Innovation Activities, OECD Publishing. doi:10.1787/9789264304604-en

Oliver, R. L. (1997). Satisfaction: A behavioral perspective on the consumer. New York, NY: Irwin-McGraw-Hill.

SaigonCoop (Producer). (2019). Saigon Coop - 30 năm nỗ lục cống hiến 1989 - 2019 [30 years foundation 1989 - 2019 of Saigon Coop]. Retrieved July 21, 2019, from http://www.saigonco-op.com.vn/

Samydai, M. J. A., Yaseen, S. G., \& Dajani, D. M. (2018). The impact of e-communication strategy 
innovation on consumer satisfaction. International Journal of Advances in Management and Economics, 4(4), 30-38.

Schneider, B., \& Bowen, D. E. (1999). Understanding customer delight and outrage. Sloan Management Review, 41(1), 35-45.

Schumpeter, J. A., \& Opie, R. (1934). The theory of economic development: An inquiry into profits, capital, credit, interest, and the business cycle. Cambridge, MA: Harvard University Press.

Selnes, F. (1993). An examination of the effect of product performance on brand reputation, satisfaction and loyalty. European Journal of Marketing, 27(9), 19-35. doi:10.1108/03090569310043179

Simon, A., \& Petnji Yaya, L. H. (2012). Improving innovation and customer satisfaction through systems integration. Industrial Management \& Data Systems, 112(7), 1026-1043. doi:10.1108/02635571211255005

Sivadas, E., \& Baker-Prewitt, J. L. (2000). An examination of the relationship between service quality, customer satisfaction, and store loyalty. International Journal of Retail \& Distribution Management, 28(2), 73-82. doi:10.1108/09590550010315223

Smith, S. (2013). Market research example: How coca-cola lost millions with this mistake. Retrieved July 20, 2019, from https:/www.qualtrics.com/blog/coca-cola-market-research/

Sundbo, J. (1997). Management of innovation in services. The Service Industries Journal, 17(3), 432-455. doi:10.1080/02642069700000028

Swan, J. E., \& Oliver, R. L. (1989). Postpurchase communications by consumers. Journal of Retailing, 65(4), 516-533.

Türkyılmaz, A., \& Özkan, C. (2007). Development of a customer satisfaction index model: An application to the Turkish mobile phone sector. Industrial Management \& Data Systems, 107(5), 672-687. doi:10.1108/02635570710750426

Vaccaro, A., Parente, R., \& Veloso, F. M. (2010). Knowledge management tools, interorganizational relationships, innovation and firm performance. Technological Forecasting and Social Change, 77(7), 1076-1089. doi:10.1016/j.techfore.2010.02.006

Weng, M. H., Ha, J. L., Wang, Y. C., \& Tsai, C. L. (2012). A study of the relationship among service innovation, customer value and customer satisfaction: An empirical study of the hotel industry in Taiwan. International Journal of Organizational Innovation, 4(3), 98-112.

Wernerfelt, B. (1984). A resource-based view of the firm. Strategic Management Journal, 5(2), 171-180. doi:10.1002/smj.4250050207

Yang, Z., \& Peterson, R. (2004). Customer perceived value, satisfaction, and loyalty: The role of switching costs. Psychology and Marketing, 21(10), 799-822. doi:10.1002/mar.20030

YuSheng, K., \& Ibrahim, M. (2019). Service innovation, service delivery and customer satisfaction and loyalty in the banking sector of Ghana. International Journal of Bank Marketing. doi:10.1108/IJBM-06-2018-0142

Zeithaml, V. (1988). Consumer perceptions of price, quality and value: A means-end model and synthesis of evidence. Journal of Marketing, 52(3), 2-22. doi:10.1177/002224298805200302

Zuñiga-Collazos, A., \& Palacio, M. (2016). Impact of image and satisfaction on marketing innovation. Journal of Technology Management \& Innovation, 11(2), 70-75. doi:10.4067/S0718-27242016000200007 